\title{
Socio-economic Evaluation of Women Homestead Farmers in Zuru Emirate, Kebbi State, Nigeria
}

\author{
Ango Adamu Kamba ${ }^{1}$, Ebenihi Ojomugbokenyode ${ }^{2}$, Tambari Ismaila Waziri ${ }^{1}$, Ahmad Nabila ${ }^{1}$ \\ ${ }^{1}$ Department of Agricultural Extension and Rural Development, Faculty of Agriculture, Usmanu Danfodiyo University, Sokoto, Nigeria \\ ${ }^{2}$ Department of Agricultural Extension and Rural Development, Faculty of Agriculture and Engineering, Federal University, Dutsin-Ma, \\ Nigeria
}

\author{
Email address: \\ aakamba2@gmail.com (A. A. Kamba), ango.adamu@udusok.edu.ng (A. A. Kamba) \\ ${ }^{*}$ Corresponding author
}

\section{To cite this article:}

Ango Adamu Kamba, Ebenihi Ojomugbokenyode, Tambari Ismaila Waziri, Ahmad Nabila. Socio-economic Evaluation of Women Homestead Farmers in Zuru Emirate, Kebbi State, Nigeria. International Journal of Applied Agricultural Sciences.

Vol. 7, No. 2, 2021, pp. 84-88. doi: 10.11648/j.ijaas.20210702.12

Received: October 12, 2020; Accepted: October 23, 2020; Published: March 12, 2021

\begin{abstract}
Homestead farming system is a well-established land use systems where different crops, including trees, are grown in combination with livestock. For most people, the main aspects of homestead farming include owning a land and the buildings on it, and doing small-scale farming with the goal of being self-sufficient in food supply and an act of reducing poverty. This study evaluated the socio-economic characteristics of the homestead farmers in Zuru Emirate, Kebbi State, Nigeria. A multi-stage sampling technique was used to arrive at the sample size of 120 women homestead farmers in the study area. Data for the study were collected through the use of structured questionnaire. Descriptive and inferential statistics were used to analyze the data obtained. Findings of the study revealed that the homestead farmers had a mean age of 38 years, with majority (74.2\%) of them being married and with appreciable farming experience. More than half $(57.9 \%)$ of the women homestead farmers were into crop gardening as primary occupation; selling of agricultural products as secondary occupation (53.3\%) with 6-10 family members in the household $(62.5 \%)$. The study also revealed a significant relationship between the extent of engagement in homestead farming and the secondary occupation of the homestead farmers $(\mathrm{P}<0.05)$. The study therefore, concluded that homestead farming was not influenced by all the socio-economic characteristics of women homestead farmers and hence recommended the provision of adequate women extension workers for training of the farmers.
\end{abstract}

Keywords: Evaluation, Socio-Economic Characteristics, Women, Homestead Farmers, Kebbi State, Nigeria

\section{Background of the Study}

Homestead farming arose as a complementary farming system that involves planting crops/raising of livestock around residential houses [1]. The advantage of the system lies on easy access to farm products at convenience [2]. In addition, the socio-economic advantage of homestead farming among the women homestead farmers in Nigeria is primarily linked to the initiative of how to increase the productivity of farming enterprises at a household level, in order to reduce the reliance of a single commodity for household consumption demand and to generate income for sustaining the livelihood of family of the homestead farmers [3]. In contrast, the practice of homestead farming is principally based on the concept of utilizing the nearby farmlands that are ecologically sound, economically viable and socially acceptable by homestead farmers. Homestead farming in Kebbi State according to oral account is generally perceived as a subsistence system of farming that promotes the livelihood of women homestead farmers at a household level; where for instance, the livestock husbandry, poultry, fishery and crop gardening are being practiced in accordance with the philosophy of indigenous knowledge. According to preliminary survey, Zuru Emirate is among the predominant areas where women are actively engaged as key players in homestead farming for achieving a sustainable livelihood [4]. Generally, empirical studies in relation to the women homestead farmers' engagement on homestead farming in 
Zuru Emirate was very scarce. In accordance with this expression, the objective of the study was based on the socioeconomic evaluation of homestead farmers in the study area. The study also hypothesized a non significant relationship between the extent of women engagement in homestead farming and their socio-economic characteristics.

\section{Research Methodology}

\subsection{Study Area}

Zuru Emirate is among the four Emirates of Kebbi State located in the Northern Guinea Savannah Agro-Ecological Zone of Nigeria and it lies between Latitude $11^{\circ} 25^{\prime} 49^{\prime \prime} \mathrm{N}$ and a Longitude of 5'14'15' E with a total land mass of $653 \mathrm{~km}^{2}$. Danko-Wasagu, Fakai, Sakaba and Zuruare the 4 Local Government Areas that made up the Emirate with a population of 171,287 people based on 2018 projection. The people of the emirate are predominantly farmers and it has a common boundary with Zamfara State to the north and Niger state to the south [5]. However, rainfall of Zuru Emirate is predicted to have started in May and ceases in October every year with an average rainfall of $771 \mathrm{~mm} \mathrm{[6].}$

\subsection{Sampling Procedure and Sample Size}

Four stage sampling technique was used to arrive at the sample size of the study. At the first stage, two Local Government Areas (LGAs) out of the 4 LGAs within the Zuru Emirate were purposively selected on the basis of active engagement of women in homestead farming. At the second stage, two districts from each of the selected LGAs were randomly selected. At the third stage, two villages from each of the selected districts were randomly selected. At the fourth stage, proportionate selection of $12 \%$ of the farmers was done to arrive at the sample size of 120 women homestead farmers.

\subsection{Data Collection and Analysis}

Data for the study were collected through the interview schedule using structured questionnaire. Descriptive statistics such as percentage mean and charts were used to evaluate the socio-economic characteristics of the women homestead farmers while inferential statistic (Chi-square) was used to test the study hypothesis.

\section{Results and Discussion}

\subsection{Age}

Figure 1 revealed that $35.8 \%$ of women homestead farmers were within the ages of $31-40$ years, $33.3 \%$ were within the age ranges of 20-30 years, $17.5 \%$ were within the age bracket of 51years and above. Therefore, a mean age of 38 years was realized, indicating that the women homestead farmers were in active and productive ages. This revelation is in accordance with [7] reported that the active and productive age was described as the period upon which the women are capable and energetic to carry out farming activities efficiently and effectively.

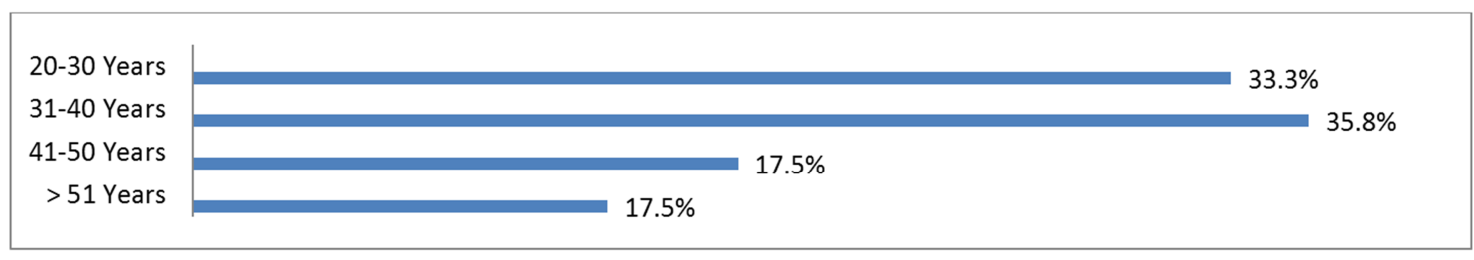

Figure 1. A ge distribution of women homestead farmers.

\subsection{Marital Status}

Figure 2 revealed that majority $(74.2 \%)$ of women homestead farmers were married, $15.0 \%$ were single and only few $(10.8 \%)$ of them were widow. The concentration of married homestead farmers in the study area was attributed to the socio-cultural obligation that discourages women to remain without being married at a certain age of her life time.
This revelation is in corroboration with [8] reported that the high number of married women in Northern part of Nigeria was attributed to the influence of socio-cultural obligations. Furthermore, [9] reported that marriage is encouraged in the northern part of Nigeria as it's considered as the sign of responsibility and religious obligation.

\begin{tabular}{|ccc|}
\hline $74.2 \%$ & $15.0 \%$ & $10.8 \%$ \\
\hline Married & Single & Widow \\
\hline
\end{tabular}

Figure 2. Marital status distribution of women homestead farmers.

\subsection{Educational Attainment}

Results in Figure 3 further revealed that most (69.2\%) of women homestead farmers had indigenous knowledge of homestead farming, $13.3 \%$ had primary school education, $9.2 \%$ had secondary school education and $8.3 \%$ of the women homestead farmers had no any educational attainment. Hence, 
indigenous knowledge was observed as the knowledge utilized by majority of women homestead farmers in carrying out homestead farming activities. The idea behind utilizing indigenous knowledge among the women homestead farmers was commonly attributed to the gap between the ratio of farmers and extension workers that ultimately lead to insufficient agricultural extension education provision within the landscape of farming communities. This finding is in line with [10] who reported that the gap in ratio between farmers and extension workers within the farming communities has reduced the quality of agricultural extension education in Nigeria.

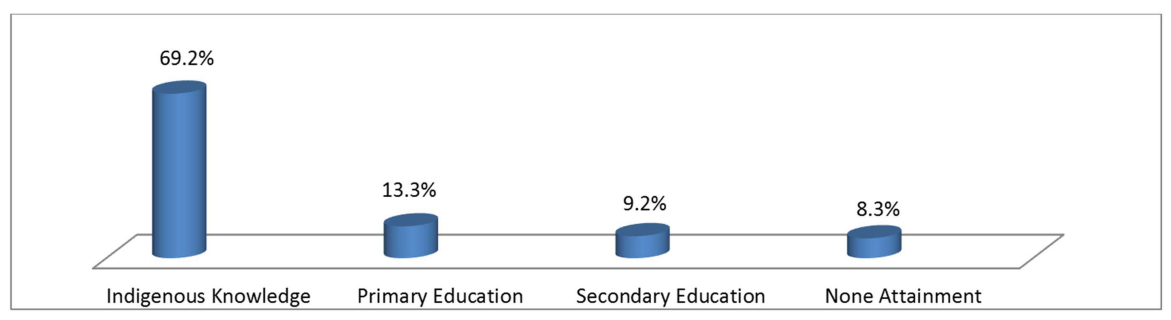

Figure 3. Distribution of women homestead farmers according to educational attainment.

\subsection{Primary Occupation}

Results in figure 4 revealed that more than half (57.9\%) of women homestead farmers were into crop gardening as primary occupation, $21.6 \%$ were engaged into vegetables gardening, $17.4 \%$ were into livestock husbandry and $1.7 \%$ of them were occupied by fish farming. This finding therefore, indicates that the women homestead farmers engaged into homestead farming purposely to improve the standard of living of their households due to prevalence of scarce resources within the ambient environment of the farming communities. This finding is in agreement with [11] posited that many people were into farming business purposely to improve upon their living standard and fight against the adverse effects of poverty attributed by limited capital resources.

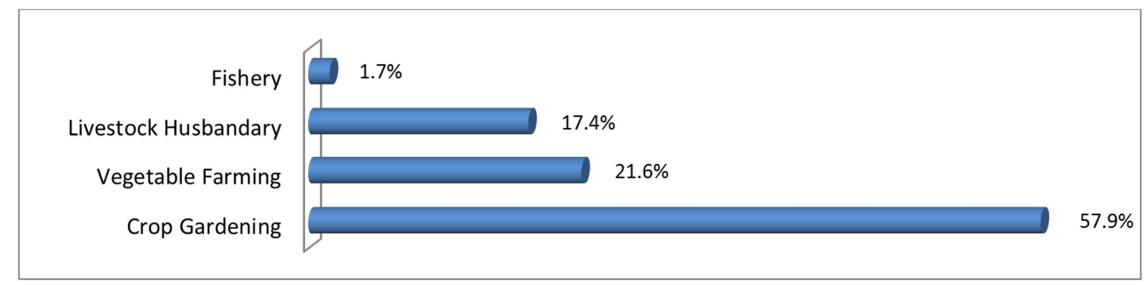

Figure 4. Distribution of women homestead farmers based on primary occupation.

\subsection{Secondary Occupation}

The reason behind engaging in secondary occupation by majority of farmers is to generate additional income that aids in the operations of the primary occupation. Results in Figure 5 revealed that more than half $(53.3 \%)$ of the women homestead farmers were engaged in the activities of selling agricultural products, $25.0 \%$ of them were into processing of agricultural produce and few $(20.8 \%)$ were into preserving agricultural products. Thus, the resources generated from the secondary occupation of the women homestead farmers were being recycled to sustain the homestead farming. Though, the women homestead farmers were found to tend more in venturing into selling of agricultural products to generate needed financial resources compared to other secondary occupations. This finding is in conformity [12] reported that secondary occupation of farmers usually exposed them into selling of agricultural produce to generate additional income that could balance up the gap of insufficient financial resources.

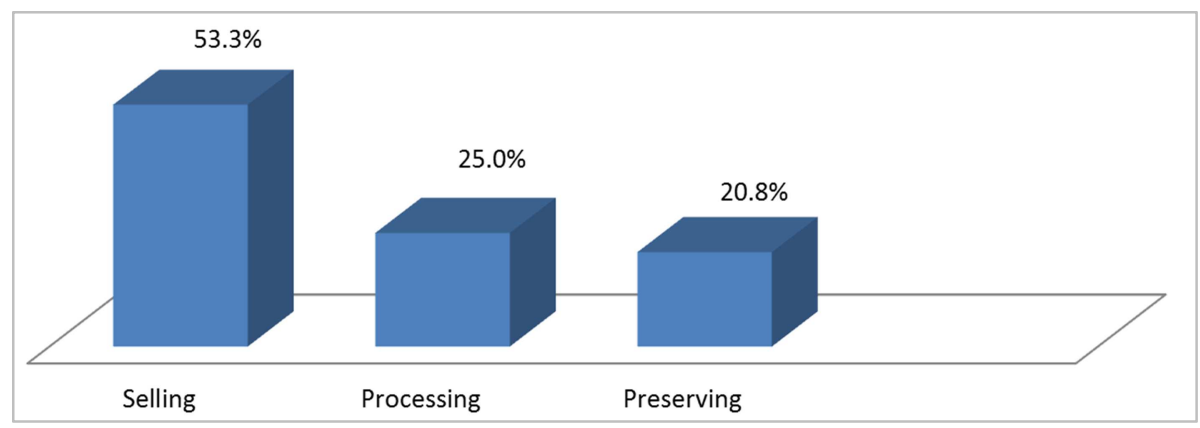

Figure 5. Distribution of women homestead farmers according to their secondary occupation. 


\subsection{Household Size}

Figure 6 revealed that most $(62.5 \%)$ of the women homestead farmers had 6-10 family members, $16.6 \%$ of them had 1-5 family members while few (20.8\%) of women homestead farmers had 11-15 family members. The findings imply that the women homestead farmers had moderate to large family size and most of them were from the farming households, where polygamy was commonly practiced and used as a source of family labour for farming activities. This finding is in agreement with [13] who reported that farmers with large family members due to influence of polygamy were used as a source of farm labour for family farming practices.

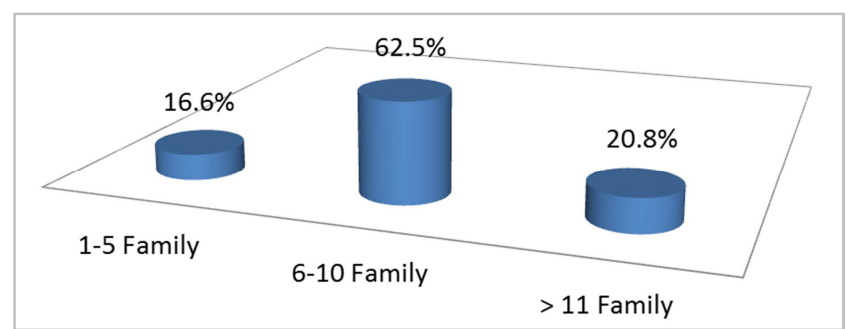

Figure 6. Distribution of women homestead farmers according to family size.

\subsection{Farm Size}

As could be seen in figure 7, most (60.0\%) of women homestead farmers had less than 1 acre of farmland used for homestead farming and $40.0 \%$ of them had a farm size of more than 1 acre. Utilization of small plot of farmlands for homestead farming was attributed to the factor of land tenure due to influence of inheritance where a plot of land belonging to a deceased person is shared among his/her heirs. This finding is in accordance with [14] posited that inheritance among the farming communities was found to be the common mode of land acquisition for farming practices in Northern Nigeria and which mostly leads to land fragmentation in to pieces of less than one hectare. Based on [15] inheritance is the common mode of acquiring land in northern Nigeria, and this is based on strict Shari' a law practiced, where land of any deceased person is normally passed on to his/her heirs. Through this process, every member of the community may get at least a portion of land from his ancestors. The Shari' a law has undermined the customary principles which emphasized collective ownership of land. It also established rules concerning transfer, inheritance of land and commercial transactions of land in northern Nigeria.

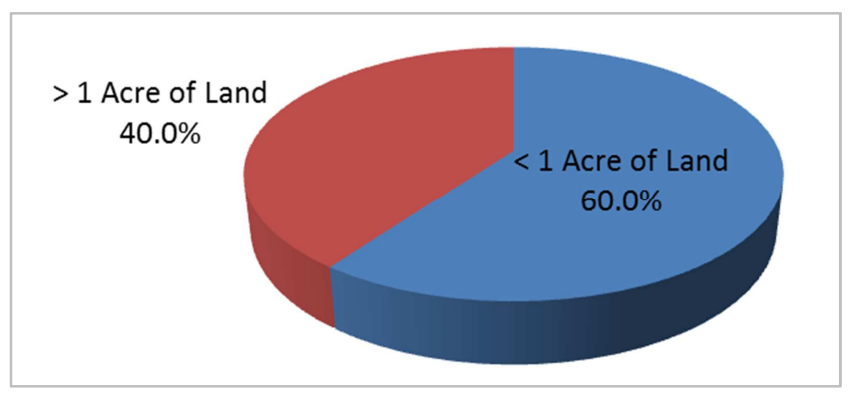

Figure 7. Distribution of women homestead farmers based on farm size.

\subsection{Hypothesis: Relationship between the Extent of Women Engagement in Homestead Farming and Their Socio-economic Characteristics}

Chi-Square analysis in Table 1 revealed a significant relationship between the extent of women engagement in homestead farming and primary occupation $\left(\chi^{2}=79.5 ; \mathrm{P}<=0.00\right)$ of women homestead farmers which indicated that the primary occupation of women homestead farmers has influenced on their engagement into homestead farming, as such the null hypothesis was rejected. The analysis result further indicated a significant relationship between the extent of women engagement in homestead farming and the secondary occupation $\left(\chi^{2}=12.1 ;>p=0.006\right)$ of women homestead farmers, implying that the income generating activities of the women homestead farmers has contributed to the success achieved in the homestead business by the women.

Table 1. Extent of women engagement in homestead farming and their and socio-economic characteristics.

\begin{tabular}{|c|c|c|c|c|c|}
\hline Variable & $\chi^{2}$-value & Df & P-value & Decision & Remarks \\
\hline Extent of engagement and age & 3.60 & 3 & 0.300 & NS & Accepted \\
\hline Extent of engagement and marital status & 0.20 & 3 & 0.970 & NS & Accepted \\
\hline Extent of engagement and educational attainment & 7.60 & 4 & 0.100 & NS & Accepted \\
\hline Extent of engagement and primary occupation & 79.50 & 5 & 0.000 & $\mathrm{~S}$ & Rejected \\
\hline Extent of engagement and secondary occupation & 12.10 & 6 & 0.060 & $\mathrm{~S}$ & Rejected \\
\hline Extent of engagement and household size & 5.50 & 4 & 0.140 & NS & Accepted \\
\hline Extent of engagement and farm size & 5.50 & 3 & 0.130 & NS & Accepted \\
\hline
\end{tabular}

Source: Field Survey, 2017; NS=Not Significant; S=Significant; Df=degree of freedom

\section{Conclusion}

The study identified that majority of women homestead farmers were married, in active and productive ages and with moderated family size. The study also concluded that most of the homestead farmers used their indigenous knowledge to operate homestead business due to lack of contact with extension workers and subsequent trainings which resulted in to cultivating small plots of farmland (1-2 acres). The study further revealed a significant relationship between the engagement of women homestead farmers in homestead farming with their primary and secondary occupations. 


\section{Recommendations}

1. Non-married women should be encouraged to be part of homestead farming due to its effort in improving livelihood of the women farmers.

2. Provision of adequate women extension workers by government are required to strengthen the performance of women homestead farmers.

3. Relevant agricultural stakeholders are recommended to support women homestead farmers to practice livestock husbandry and fishery in equal proportion with vegetables farming and crop gardening as a means of livelihood improvement.

4. Adequate trainings and extension contacts are recommended for the women homestead farmers.

\section{References}

[1] Akpan, S. B. and Essien, U. A. (2019). Productivity of Homestead based Yam Farmers: An Empirical Evidence from Southern Cross River State, Nigeria. Journal of Sustainable Development in Agriculture and Environment, 6 (1), 13-24.

[2] International Food Policy Research Institute - IFPRI (2019). Global Food Policy Report. Retrieved from https://reliefweb.int/sites/reliefweb.int/files/resources/2019_G FPR_Full\%20Report_EMBARGOED.pdf on $22^{\text {nd }}$ October, 2020 at $10: 48 \mathrm{Am}$.

[3] John, J. (2014). Homestead Farming in Kerala: A multifaceted land-use system. Journal of Foundation for Agrarian Studies 4 (1), 48-90.

[4] Baba, M. D., Dabai, J. S., Sanchi, I. D. and Sabo, A. Y. (2014). Profitability of Traditional Honey Production in Zuru Emirate, Kebbi State, Nigeria. Profitability of Traditional Honey Production In Zuru Emirate, Kebbi State, Nigeria.

[5] Kebbi State Government (2018). The Directorate of Information, the Diary of Kebbi State Government, Nigeria.

[6] Nigerian Meteorological Agency (2018). Seasonal rainfall prediction: Detailed city by city predicted onset and cessation dates of growing season, length of season and seasonal rainfall amount.
[7] Tambari, I. W., Dalhatu, M. \& Attahiru, M. (2014). Effects of improved oil processing technology to the livelihood of groundnut oil processors in Sokoto Metropolis, Nigeria. International Journal of Applied Research and Technology 3 (11), 15-20.

[8] Abubakar, B. Z., Ango, A. K. and Buhari, U. B. (2009). The role of mass media in disseminating agricultural information to farmers in Birnin Kebbi Local Government, Kebbi State: A Case Study of State Fadama II Development Project. Journal of Agricultural Extension, 13 (2), 34-42.

[9] Ango, A. K., Maikasuwa, M. A. and Sidi, H. M. (2018). Role of Fadam III Programme in Empowering the Socio-economic Status of the Sokoto State Participating Women through Crop Production Assets. Equity Journal of Science and Technology, 5 (1), 14-22.

[10] Ladan, E. O. and Wahab, A. A. (2014). Bridging the gap towards an efficient extension service delivery, A Paper presented at 19th Annual National Conference of Agricultural Extension Society of Nigeria on April 27-30, 2014 at Federal University of Technology, Oweri, Imo State, Nigeria.

[11] Omotoso, A. B., Ogunsola, T. O, Ajibade, A. J. and Ayodele, M. A. (2018). Determinants of poverty in farming households in Oyo State, Nigeria. International Journal of Agriculture and Development Studies 3 (1), 1-5.

[12] Sani, S. (2018). Gender roles in rice value chain activities among Fadama III Additional Finance Project Beneficiaries in Sokoto State, Nigeria. Unpublished Dissertation, Faculty of Agriculture, Usmanu Danfodiyo University, Sokoto.

[13] Manga, A. T. (2012). Role of International Fund for Agricultural Development in Poverty Reduction among Women in Kebbi State, Nigeria. Unpublished Dissertation, Faculty of Agriculture, Usmanu Danfodiyo University, Sokoto.

[14] Ango, A. K., Ibrahim, S. A. \& Tambari, I. W. (2017). Roles of agricultural extension workers in disseminating agricultural technologies to vegetable farmers under Jibia Irrigation Project, Katsina State, Nigeria. International Journal of Agriculture and Development Studies 2 (1), 134-141.

[15] Ango, A. K. (1999). "Comparative analysis of the Impact of Bakolori Irrigation Project and Fadama Development Programme of Sokoto/Kebbi Watershed". M.Sc. Thesis, University of Ibadan, Nigeria, 54. 